\title{
NOTA
}

\section{COMPARISON OF H/AL STOICHIOMETRY OF MINERAL AND ORGANIC SOILS IN BRAZIL ${ }^{(1)}$}

\author{
Daniel Vidal Perez ${ }^{(2)}$, Lúcia Helena Cunha dos Anjos ${ }^{(3)}$, Adierson Gilvani \\ Ebeling $^{(4)} \&$ Marcos Gervasio Pereira ${ }^{(3)}$
}

\begin{abstract}
SUMMARY
Exchangeable Al has been used as a criterion for the calculation of lime requirement in several Brazilian States. However, the laboratory method with extraction by a $1 \mathrm{~mol} \mathrm{~L}^{-1} \mathrm{KCl}$ solution followed by indirect alkaline titration is not accurate for some Brazilian soils, mainly in the case of soils with high organic matter content. The objective of this study was therefore to evaluate the stoichiometry of $\mathrm{H}^{+} / \mathrm{Al}^{3+}$ in $\mathrm{KCl}$ soil extracts. The results suggested that organically complexed $\mathrm{Al}$ is the main contributor to exchangeable acidity in soils enriched with organic matter. Liming recommendations for organic soils based exclusively on exchangeable $\mathrm{Al}$ determined by the $\mathrm{NaOH}$ titration method should therefore be revised.
\end{abstract}

Index terms: acid-base titration; ICP-OES; KCl; Histosols.

\section{RESUMO: COMPARAÇÃO DA ESTEQUIOMETRIA H/Al EM SOLOS MINERAIS E ORGÂNICOS BRASILEIROS}

A determinação de alumínio trocável é utilizada como critério para cálculo de calagem em vários estados brasileiros. Contudo, a determinação indireta pela titulação com $\mathrm{NaOH}$, após extração com solução de $\mathrm{KCl} 1 \mathrm{~mol} \mathrm{~L} \mathrm{~L}^{-1}$, pode não ser adequada para certos tipos de solos brasileiros, notadamente aqueles que apresentem altos teores de carbono orgânico. Dessa forma, o principal objetivo deste trabalho foi avaliar a estequiometria da relação $\mathrm{H}^{+} / \mathrm{Al}^{3+} \mathrm{em}$ extratos de $\mathrm{KCl}$. Os resultados obtidos sugerem que o Al complexado pela matéria orgânica,

\footnotetext{
(1) Work presented at the 18th World Congress of Soil Science hold at Philadelphia, Pennsylvania, USA. Recebido para publicação em novembro de 2008 e aprovado em maio de 2009.

(2) Researcher, Embrapa Solos, Jardim Botânico 1024, CEP 22460-000 Rio de Janeiro (RJ). E-mail: daniel@cnps.embrapa.br

(3) Professor, Soils Dept., Universidade Federal Rural do Rio de Janeiro - UFRRJ. Km 47 CEP 23890-000 Seropédica (RJ). E-mails: lanjos@ufrrj.br; gervasio@ufrrj.br

(4) Ph.D. Student, Soils Dept., UFRRJ. E-mail: adiersonge@gmail.com
} 


\begin{abstract}
em solos orgânicos, é o principal contribuinte para a acidez trocável obtida por titulação. Dessa forma, a recomendação de calagem em solos orgânicos baseado somente na determinação de alumínio trocável por titulação com $\mathrm{NaOH}$ deve ser revista.
\end{abstract}

Termos de indexação: titulação ácido-base; ICP-OES; KCl; Organossolos.

\section{INTRODUCTION}

The determination of $\mathrm{Al}$ is a permanent concern of soil fertility management. Soil chemists are constantly testing methods that take into account the effective soil exchange capacity, organic matter content, texture, and the $\mathrm{pH}$-dependent charges of various clays minerals (Menzies, 2003).

The titrimetric determination of $\mathrm{Al}^{3+}$ in $1 \mathrm{~mol} \mathrm{~L}^{-1}$ $\mathrm{KCl}$ soil extract using bromothymol blue as indicator has been widely used in Brazil (Raij et al., 1994; Bernardi et al., 2002). However, in fact, this procedure determines $\mathrm{H}^{+}$in the $\mathrm{KCl}$ extract. This is recognized as the exchangeable acidity (Sposito, 1989). In this context, there is therefore no differentiation between the "exchangeable $\mathrm{H}^{+}$" and $\mathrm{H}^{+}$developed by $\mathrm{Al}^{3+}$ hydrolysis.

From very acid mineral soils with neutral salt solutions, such as $\mathrm{KCl}$, more $\mathrm{Al}^{3+}$ than $\mathrm{H}^{+}$is extracted (Veith, 1977; Bloom et al., 2005), while in the organic soil horizons, the quantity of extractable $\mathrm{H}^{+}$typically exceeds Al ${ }^{3+}$ (Bloom et al., 2005). But Sparks (2003) observed that much of the $\mathrm{H}^{+}$that appears to be exchangeable in organic soils may be due to $\mathrm{Al}^{3+}$ hydrolysis in the organic matter resulting in $\mathrm{H}^{+}$.

An important tool for the differentiation between $\mathrm{H}^{+}$and $\mathrm{Al}^{3+}$ is based on the use of the titration/backtitration procedure (Bertsch \& Bloom, 1996). This method was first described by Yuan (1959). However, Coscione et al. (1998) showed the lower sensitivity of exchangeable $\mathrm{Al}^{3+}$ determined by back-titration. Al determination by spectrophotometric methods, such as ICP-OES, is doubtlessly more sensitive and reliable (Bertsch \& Bloom, 1996). The purpose of this study was therefore the evaluation of $\mathrm{H}$ and $\mathrm{Al}$ in $1 \mathrm{~mol} \mathrm{~L}^{-1}$ $\mathrm{KCl}$ extracts to determine whether the theoretical value of 3 of $\mathrm{Al}$ hydrolysis predominates in the exchangeable acidity.

\section{MATERIALS AND METHODS}

The method for exchangeable $\mathrm{Al}$ extraction of most Brazilian soil laboratories is based on the $\mathrm{Al}$ exchange from the surface of soil colloids using a non-buffered $1 \mathrm{~mol} \mathrm{~L}^{-1} \mathrm{KCl}$ solution (Embrapa, 1997; Bernardi et al., 2002). A soil:solution mixture, ratio 1:10, was vigorously shaken for $5 \mathrm{~min}$ and left to stand overnight. Then a $25 \mathrm{~mL}$ aliquot of the supernatant was sampled and $\mathrm{Al}$ was indirectly quantified by titration with $0.025 \mathrm{~mol} \mathrm{~L}^{-1} \mathrm{NaOH}$ using
Bromothymol Blue as indicator. In this case, each mol of $\mathrm{NaOH}$ neutralizes $1 \mathrm{~mol} \mathrm{H}$. Thus, the number of $\mathrm{H}^{+}$mmoles in the $25 \mathrm{~mL}$ aliquot is (A x 0.025), where $\mathrm{A}$ is the volume $(\mathrm{mL})$ of $\mathrm{NaOH}$ consumed in titration. Considering that the initial volume of $\mathrm{KCl}$ was $100 \mathrm{~mL}$ and the soil mass was $10 \mathrm{~g}$, the result could be expressed as (A x 10) mmol kg-1 or A cmol kg-1 of $\mathrm{H}^{+}$. For further discussions in the text, this type of mass concentration unit will be used, since it expresses the real titration, i.e., $\mathrm{H}^{+}$rather than $\mathrm{Al}^{3+}$. However, to clarify the use of titration in $\mathrm{Al}^{3+}$ routine analysis, the full calculation will be shown here. To express the result in terms of $\mathrm{Al}^{3+}$, it must be assumed that each $\mathrm{Al}^{3+}$ produces $3 \mathrm{H}^{+}$after complete hydrolysis. Thus, the result would be expressed as (A x 10)/ $3 \mathrm{mmol} \mathrm{kg}-1$ or $(\mathrm{A} / 3) \mathrm{cmol} \mathrm{kg}^{-1}$ of $\mathrm{Al}^{3+}$. Since the mmol Al${ }^{3+}$ is equivalent to $3 \mathrm{mmol}_{\mathrm{c}} \mathrm{Al}^{3+}$, the final result will be expressed as (A x 10) mmol $_{\mathrm{c}} \mathrm{kg}^{-1}$ or A $\mathrm{cmol}_{\mathrm{c}} \mathrm{kg}^{-1}$ of $\mathrm{Al}^{3+}$.

For a direct quantification of $\mathrm{Al}$ in the $\mathrm{KCl}$ extract, another aliquot of the supernatant was analyzed using an inductively coupled plasma atomic emission spectrometer (Perkin Elmer Optima 3000). The operating frequency was $50-60 \mathrm{MHz}$ at a power of $1,500 \mathrm{~W}$ with a torch argon flow rate of $15 \mathrm{~L} \mathrm{~min}^{-1}$. The selected $\mathrm{Al}$ atomic line was at $308.211 \mathrm{~nm}$. A nitrogen gas purge flow rate of $5.0 \mathrm{~L} \mathrm{~min}^{-1}$ was used throughout the analysis. The sample flow rate was $2.0 \mathrm{~L} \mathrm{~min}^{-1}$. In this case, the result was expressed as $\mathrm{B} \mathrm{mg} \mathrm{kg}{ }^{-1}$ of $\mathrm{Al}^{3+}$, considering that the initial volume of $\mathrm{KCl}$ was $100 \mathrm{~mL}$ and the soil mass was $10 \mathrm{~g}$. Since the $\mathrm{mmol}$ of $\mathrm{Al}$ is, approximately, $27 \mathrm{mg}$, the result could be expressed as $(\mathrm{B} / 27) \mathrm{mmol} \mathrm{kg}{ }^{-1}$ or $(\mathrm{B} / 270)$ $\mathrm{cmol} \mathrm{kg}{ }^{-1}$ of $\mathrm{Al}^{3+}$. For further discussions in the text, this kind of mass concentration unit will be used, since it expresses the real mass concentration of the element. However, to clarify the use of spectrophotometric determinations in $\mathrm{Al}^{3+}$ routine analysis, we will show the full calculation. Since the $\mathrm{mmol} \mathrm{Al}^{3+}$ is equivalent to $3 \mathrm{mmol}_{\mathrm{c}} \mathrm{Al}^{3+}$, the final result will be expressed as (B/9) $\mathrm{mmol}_{\mathrm{c}} \mathrm{kg}^{-1}$ or $(\mathrm{B} / 90) \mathrm{cmol}_{\mathrm{c}} \mathrm{kg}^{-1}$ of $\mathrm{Al}^{3+}$.

In the case of soils with high organic matter content, $\mathrm{Al}$ extraction by $\mathrm{CuCl}_{2} 0.2 \mathrm{~mol} \mathrm{~L}^{-1}$ was performed according to Bertsch \& Bloom (1996). The $\mathrm{Al}$ determination followed the ICP-OES procedure described above.

Thirty seven acid soil samples were selected representing different soil classes (Oxisol, Ultisol, Inceptisol, Entisol, Histosol) from different Brazilian States (RJ, AM, MS, SP, AL, PB, PE, PR, MG, and DF). Their main properties are shown in table 1. 
Table 1. Soil classification and localization of 37 selected soil samples

\begin{tabular}{|c|c|c|c|c|c|}
\hline \multirow{2}{*}{ Sample } & \multirow{2}{*}{ Horizon } & \multirow{2}{*}{ Depth } & \multicolumn{2}{|c|}{ Soil classification ${ }^{(1)}$} & \multirow{2}{*}{ County, State } \\
\hline & & & SiBCS & Soil taxonomy & \\
\hline & & $\mathrm{cm}$ & & & \\
\hline 03.0954 & $\mathrm{~A} 2$ & $6-20$ & Latossolo Vermelho-Amarelo & Oxisol & Itaperuna, RJ \\
\hline 03.0955 & $\mathrm{BA}$ & $20-39$ & Latossolo Vermelho-Amarelo & Oxisol & Itaperuna, RJ \\
\hline 03.0988 & $\mathrm{~A} 1$ & $0-17$ & Cambissolo Húmico & Inceptisol & Bom Jesus de Itabapoana, RJ \\
\hline 03.0989 & $\mathrm{~A} 2$ & $17-46$ & Cambissolo Húmico & Inceptisol & Bom Jesus de Itabapoana, RJ \\
\hline 03.1484 & $\mathrm{~A} 1$ & $0-22$ & Latossolo Amarelo & Oxisol & Porciuncula, RJ \\
\hline 03.1485 & $\mathrm{~A} 2$ & $22-42$ & Latossolo Amarelo & Oxisol & Porciuncula, RJ \\
\hline 04.0224 & $\mathrm{Bi} 2$ & $63-98$ & Cambissolo Háplico & Inceptisol & Benjamin Constant, AM \\
\hline 04.0225 & $\mathrm{BC}$ & $109-121$ & Cambissolo Háplico & Inceptisol & Benjamin Constant, AM \\
\hline 04.0217 & Bi1 & $24-62$ & Cambissolo Háplico & Inceptisol & Benjamin Constant, AM \\
\hline 04.1229 & $\mathrm{AB}$ & $20-42$ & Latossolo Vermelho & Oxisol & Ponta Porã, MS \\
\hline 04.1230 & BA & $42-63$ & Latossolo Vermelho & Oxisol & Ponta Porã, MS \\
\hline 04.1252 & Cgf & $83-110$ & Plintossolo Háplico & Entisol & Bela Vista, MS \\
\hline 04.1386 & Bt1 & $36-52$ & Argissolo Vermelho & Ultisol & Caracol, MS \\
\hline 04.1387 & Bt2 & $52-88$ & Argissolo Vermelho & Ultisol & Caracol, MS \\
\hline 04.1408 & Bt2 & $60-80$ & Argissolo Amarelo plíntico & Ultisol & Bela Vista, MS \\
\hline 05.0577 & $\mathrm{C} 2$ & $52-100$ & Neossolo Quartzarênico & Entisol & Santa Maria Boa Vista, PB \\
\hline 05.0578 & $\mathrm{C} 3$ & $100-150$ & Neossolo Quartzarênico & Entisol & Santa Maria Boa Vista, PB \\
\hline 05.0579 & $\mathrm{C} 4$ & $152-200$ & Neossolo Quartzarênico & Entisol & Santa Maria Boa Vista, PB \\
\hline RJ1O1 & $\mathrm{O}$ & -- & Cambissolo Húmico & Inceptisol & Itatiaia, RJ \\
\hline RJ1O2 & $\mathrm{O}$ & -- & Cambissolo Húmico & Inceptisol & Itatiaia, RJ \\
\hline RJ1O3 & $\mathrm{O}$ & -- & Cambissolo Húmico & Inceptisol & Itatiaia, RJ \\
\hline RJ 104 & $\mathrm{O}$ & -- & Cambissolo Húmico & Inceptisol & Itatiaia, RJ \\
\hline RJ4 H2 & $\mathrm{H}$ & -- & Organossolo Mésico & Histosol & Nova Friburgo, RJ \\
\hline RJ4 H3 & $\mathrm{H}$ & -- & Organossolo Mésico & Histosol & Nova Friburgo, RJ \\
\hline RJ4 H4 & $\mathrm{H}$ & -- & Organossolo Mésico & Histosol & Nova Friburgo, RJ \\
\hline PR2 H1 & $\mathrm{H}$ & -- & Organossolo Mésico & Histosol & Tijucas do Sul, PR \\
\hline $\mathrm{PR} 2 \mathrm{H} 2$ & $\mathrm{H}$ & -- & Organossolo Mésico & Histosol & Tijucas do Sul, PR \\
\hline PR2 H3 & $\mathrm{H}$ & -- & Organossolo Mésico & Histosol & Tijucas do Sul, PR \\
\hline AL2 H1 & $\mathrm{H}$ & -- & Organossolo Tiomórfico & Histosol & Coruripe, $\mathrm{AL}$ \\
\hline AL2 H2 & $\mathrm{H}$ & -- & Organossolo Tiomórfico & Histosol & Coruripe, AL \\
\hline SP1 HP1 & $\mathrm{Hp}$ & -- & Organossolo Mésico & Histosol & Taubaté, SP \\
\hline SP1 HP2 & $\mathrm{Hp}$ & -- & Organossolo Mésico & Histosol & Taubaté, SP \\
\hline DF1 H1 & $\mathrm{H}$ & -- & Organossolo Mésico & Histosol & Guara, DF \\
\hline DF1 H2 & $\mathrm{H}$ & -- & Organossolo Mésico & Histosol & Guara, DF \\
\hline $\mathrm{DF} 1 \mathrm{H} 3$ & $\mathrm{H}$ & -- & Organossolo Mésico & Histosol & Guara, DF \\
\hline $\mathrm{MS} 22 \mathrm{H}$ & $\mathrm{H}$ & -- & Organossolo Mésico & Histosol & Eldorado, MS \\
\hline MG2 H2 & $\mathrm{H}$ & -- & Organossolo Mésico & Histosol & Coronel Pacheco, MG \\
\hline
\end{tabular}

${ }^{(1)}$ SiBCS: Brazilian Soil Classification System (Embrapa, 2006); Soil Taxonomy (Soil Survey Staff, 1999).

\section{RESULTS AND DISCUSSION}

In a first approach, it is possible to arrange the soil samples in two groups (Tables 2 and 3). The first (Table 2) consisted of 18 horizons of mineral soils where the main dominant clay mineralogy is kaolinite and/or iron/aluminum oxy-hydroxides. In this group, the mean $\mathrm{H} / \mathrm{Al}$ ratio was around 3.4. In addition to the potential titration errors in a routine aluminum analyses, the presence of soluble $\mathrm{Mn}^{2+}$ and $\mathrm{Fe}^{3+}$ in $\mathrm{KCl}$ soil extract (Table 2 ) could represent a small contribution of $\mathrm{H}^{+}$through the hydrolysis of these metals, which would explain a positive variation from the expected 3.0 ratio. Our results corroborate the findings of McLean (1976), Veith (1977) and Bloom et al. (2005) that most of the protons measured in the salt extract of mineral soils, i.e., the exchangeable acidity, may come from the hydrolysis of exchangeable $\mathrm{Al}^{3+}$.

The second group (Table 3) was composed of organic horizons with a $\mathrm{H} / \mathrm{Al}$ ratio of around 0.4 . In this case, the lower $\mathrm{H}^{+}$concentration suggested that the "exchangeable $\mathrm{H}^{+}$" pool was not the major part of exchangeable acidity in the studied organic soils. This may be explained by the findings of Ross et al. (2008). They showed that the quantity of exchangeable $\mathrm{H}^{+}$ may be insignificant at a $\mathrm{pH}$ above 4.5. The mean $\mathrm{pH}$ of the studied organic soils was around 4.9 (Table 3 ).

Another fact that corroborates the insignificant contribution of exchangeable $\mathrm{H}^{+}$to exchangeable acidity is related to the stoichiometry of the organic- 
Table 2. Some chemical analyses of 18 mineral soil samples

\begin{tabular}{|c|c|c|c|c|c|c|c|}
\hline Sample & $\mathrm{Al}-\mathrm{ICP} \mathbf{P}^{(1)}$ & H-Tit $^{(2)}$ & H/Al & Organic $\mathbf{C}^{(3)}$ & pH & $\mathrm{Fe}^{(1)}$ & $\mathbf{M n}{ }^{(1)}$ \\
\hline & \multicolumn{2}{|c|}{$\mathrm{mmol} \mathrm{kg}^{-1}$} & & $\mathrm{~g} \mathrm{~kg}^{-1}$ & water & \multicolumn{2}{|c|}{$\ldots \mathrm{mmol} \mathrm{kg}{ }^{-1}$} \\
\hline 03.0954 & 3.9 & 15.0 & 3.9 & 12.1 & 4.2 & 0.22 & 0.08 \\
\hline 03.0955 & 3.8 & 14.0 & 3.7 & 7.9 & 4.4 & 0.14 & 0.08 \\
\hline 03.0988 & 5.0 & 16.0 & 3.2 & 39.7 & 4.7 & 0.71 & 0.09 \\
\hline 03.0989 & 4.3 & 14.0 & 3.2 & 33.3 & 4.6 & 0.60 & 0.08 \\
\hline 03.1484 & 7.7 & 27.0 & 3.5 & 23.0 & 4.3 & 0.41 & 0.08 \\
\hline 03.1485 & 7.1 & 24.0 & 3.4 & 18.7 & 4.4 & 0.33 & 0.08 \\
\hline 04.0224 & 38.0 & 124.0 & 3.3 & 3.5 & 4.9 & 0.06 & 0.09 \\
\hline 04.0225 & 35.6 & 117.0 & 3.3 & 2.6 & 5.2 & 0.05 & 0.09 \\
\hline 04.0217 & 25.0 & 82.0 & 3.3 & 6.5 & 4.8 & 0.12 & 0.09 \\
\hline 04.1229 & 7.9 & 26.0 & 3.3 & 8.8 & 4.8 & 0.16 & 0.09 \\
\hline 04.1230 & 7.6 & 26.0 & 3.4 & 8.0 & 4.7 & 0.14 & 0.09 \\
\hline 14.1252 & 14.4 & 48.0 & 3.3 & 2.3 & 5.4 & 0.04 & 0.10 \\
\hline 04.1386 & 4.2 & 14.0 & 3.3 & 4.6 & 5.1 & 0.08 & 0.09 \\
\hline 04.1387 & 8.7 & 28.0 & 3.2 & 2.4 & 5.1 & 0.04 & 0.09 \\
\hline 04.1408 & 4.4 & 15.0 & 3.4 & 3.0 & 4.8 & 0.05 & 0.09 \\
\hline 05.0577 & 4.6 & 15.0 & 3.3 & 1.5 & 4.5 & 0.03 & 0.08 \\
\hline 05.0578 & 4.8 & 17.0 & 3.6 & 1.3 & 4.4 & 0.02 & 0.08 \\
\hline 05.0579 & 5.6 & 20.0 & 3.6 & 1.0 & 4.3 & 0.02 & 0.08 \\
\hline Average & 10.7 & 35,7 & 3.4 & 10.0 & 4.7 & 0.18 & 0.09 \\
\hline $\mathrm{SD}^{(4)}$ & 10.8 & 35,0 & 0.2 & 11.4 & 0.3 & 0.20 & 0.01 \\
\hline $\mathrm{CV}(\%)^{(5)}$ & 101 & 98 & 5 & 114 & 7 & 114 & 7 \\
\hline
\end{tabular}

(1) Extracted by $1 \mathrm{~mol} \mathrm{~L}^{-1} \mathrm{KCL}$ and determined by ICP-OES. ${ }^{(2)}$ Extracted by $1 \mathrm{~mol} \mathrm{~L}{ }^{-1} \mathrm{KCL}$ and determined by acid-based titration.

${ }^{(3)}$ Determined by dichromate wet oxidation (Embrapa, 1997). ${ }^{(4)} \mathrm{SD}$ mean standard deviation. ${ }^{(5)} \mathrm{CV}$ mean coefficient of variation.

Table 3. Some chemical analyses of 19 organic soil samples studied

\begin{tabular}{|c|c|c|c|c|c|c|c|c|}
\hline Sample & $\mathrm{Al}-\mathrm{ICP}^{(1)}$ & H-Tit ${ }^{(2)}$ & $\mathrm{H} / \mathrm{Al}$ & Organic $\mathbf{C}^{(1)}$ & pH & $F e^{(1)}$ & $\mathbf{M n}^{(1)}$ & $\mathrm{Al}-\mathrm{CuCl}_{2}$ \\
\hline & \multicolumn{2}{|c|}{$\ldots \mathrm{mmol} \mathrm{kg}{ }^{-1} \_$} & & $\mathrm{g} \mathrm{kg}^{-1}$ & water & 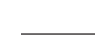 & $\mathrm{mol} \mathrm{kg}$ & ـ \\
\hline RJ1O1 & 10.4 & 5.0 & 0.5 & 63.5 & 5.1 & 0.10 & 2.08 & 255.9 \\
\hline RJ1O2 & 7.8 & 2.0 & 0.3 & 38.0 & 5.1 & 0.05 & 0.46 & 218.1 \\
\hline RJ1O3 & 12.2 & 2.0 & 0.2 & 49.9 & 5.0 & 0.20 & 0.13 & 262.2 \\
\hline RJ1O4 & 9.2 & 1.0 & 0.1 & 55.3 & 5.1 & 0.08 & 0.02 & 358.9 \\
\hline RJ4 H2 & 4.2 & 0.0 & 0.0 & 99.5 & 5.9 & 0.03 & 0.08 & 239.2 \\
\hline RJ4 H3 & 4.2 & 0.0 & 0.0 & 69.8 & 5.9 & 0.03 & 0.02 & 335.6 \\
\hline RJ4 H4 & 2.0 & 0.0 & 0.0 & 44.8 & 5.8 & 0.01 & 0.02 & 337.4 \\
\hline PR2 H1 & 18.2 & 7.0 & 0.4 & 144.1 & 4.4 & 0.21 & 0.41 & 411.1 \\
\hline PR2 H2 & 18.5 & 45.0 & 2.4 & 192.8 & 4.1 & 0.11 & 0.21 & 777.0 \\
\hline PR2 H3 & 31.1 & 29.0 & 0.9 & 270.0 & 4.5 & 0.16 & 0.13 & 773.0 \\
\hline AL2 H1 & 32.9 & 6.0 & 0.2 & 305.8 & 3.2 & 0.44 & 0.05 & 448.5 \\
\hline AL2 H2 & 18.2 & 13.0 & 0.7 & 508.1 & 3.0 & 0.10 & 0.03 & 118.0 \\
\hline SP1 HP1 & 31.6 & 4.0 & 0.1 & 207.4 & 5.2 & 0.16 & 0.20 & 729.6 \\
\hline SP1 HP2 & 25.3 & 3.0 & 0.1 & 144.4 & 5.1 & 0.05 & 0.04 & 590.0 \\
\hline $\mathrm{DF} 1 \mathrm{H} 1$ & 0.7 & 0.0 & 0.0 & 101.7 & 5.9 & 0.07 & 0.16 & 177.4 \\
\hline $\mathrm{DF} 1 \mathrm{H} 2$ & 11.6 & 3.0 & 0.3 & 132.4 & 5.4 & 0.25 & 0.07 & 383.0 \\
\hline DF1 H3 & 13.9 & 1.0 & 0.1 & 196.6 & 5.6 & 0.08 & 0.08 & 530.0 \\
\hline MS2 2H & 15.6 & 220 & 1.4 & 189.3 & 4.3 & 0.62 & 0.64 & 197.4 \\
\hline Average & 14.9 & 7.9 & 0.4 & 158.9 & 4.9 & 0.15 & 0.27 & 396.80 \\
\hline $\mathrm{SD}^{(4)}$ & 10.1 & 12.2 & 0.6 & 115.3 & 0.8 & 0.16 & 0.48 & 206.38 \\
\hline $\mathrm{CV}(\%)^{(5)}$ & 68 & 154 & 147 & 73 & 17 & 102 & 180 & 52 \\
\hline
\end{tabular}

(1) Extracted by $1 \mathrm{~mol} \mathrm{~L}^{-1} \mathrm{KCL}$ and determined by ICP-OES. ${ }^{(2)}$ Extracted by $1 \mathrm{~mol} \mathrm{~L}^{-1} \mathrm{KCL}$ and determined by acid-based titration.

${ }^{(3)}$ Determined by dichromate wet oxidation (Embrapa, 1997). ${ }^{(4)} \mathrm{SD}$ mean standard deviation. ${ }^{(5)} \mathrm{CV}$ mean coefficient of variation. 
bound $\mathrm{Al}$. The high values of $\mathrm{CuCl}_{2}$ extracted $\mathrm{Al}$ compared with those obtained by $\mathrm{KCl}$ (Table 3) are generally related to organic-bound $\mathrm{Al}$ (Shuman, 1990; Soon, 1993; Barra et al., 2001). In this case, there is a relative preference for hydroxyl-Al ions over $\mathrm{Al}^{3+}$ (Schnitzer \& Skinner, 1963; Bloom et al., 1979). Hargrove \& Thomas (1982) showed that as the Al content of the organic matter increased, the effective valence of the adsorbed $\mathrm{Al}$ varied from 2.12 to 0.93 . Nissinen et al. (1999) and Simonsson (2000) reported binding stoichiometry values ranging from 1.1 and 2.4 in literature. Therefore, the forced hydrolysis of organic-bound $\mathrm{Al}$ by alkaline titration should generate lower $\mathrm{H} / \mathrm{Al}$ ratio values.

The results obtained in the mineral soils showed that most of the soil exchangeable acidity is primarily due to $\mathrm{Al}^{3+}$. However, in the case of the studied organic soils, the contribution of hydroxyl Al bound to the organic matter is probably the main pool of exchangeable acidity. The contribution of exchangeable $\mathrm{H}^{+}$does not seem to be relevant for the studied soils. Considering that most authors indicate that the toxic aluminum is $\mathrm{Al}^{3+}$ and the monomeric Al-hydroxy species (Bloom et al., 2005), all liming recommendations for organic soils based exclusively on exchangeable $\mathrm{Al}$ determined by $\mathrm{NaOH}$-titration should therefore be revised. These findings corroborate the studies of Pereira et al. (2005) and Ebeling et al. (2008). They pointed out the need of new analytical routine methods to properly study and monitor the management of Histosols in Brazil. Besides, the relationship between exchangeable acidity determined by acid-based titration and $\mathrm{Al}$ determined directly by spectrophotometry (AAS or ICP) could be a useful index to characterize organic horizons.

\section{ACKNOWLEDGEMENTS}

The authors are grateful to CNPq and FAPERJ for the grants and funding support.

\section{LITERATURE CITED}

BARRA, C.M.; CURTIUS, A.J.; CAMPOS, R.C. \& PÉREZ, D.V. Evaluation of four aluminum extraction methods using selected Brazilian soils. Comm. Soil Sci. Plant Anal., 32: 1969-1980, 2001.

BERNARDI, A.C.C.; SILVA, C.A.; PÉREZ， D.V. \& MENEGUELLI, N.A. Analytical quality program of soil fertility laboratories that adopt Embrapa methods in Brazil. Comm. Soil Sci. Plant Anal., 33:2661-2672, 2002.

BERTSCH, P.M. \& BLOOM, P.R. Aluminum. In: SPARKS, D.L., ed. Methods of soil analysis. Madison, Soil Science Society of America, 1996. p.517-550. (Book Series, 5)
BLOOM, P.R.; McBRIDE, M.B. \& WEAVER, R.M. Aluminum organic matter in acid soils: Buffering and solution aluminum activity. Soil Sci. Soc. Am. J., 43:488-493, 1979.

BLOOM, P.R.; SKYLLBERG, V.L. \& SUMNER, M.E. Soil acidity. In: DICK, N.A., ed. Chemical processes in soils. Madison, Soil Science Society of America, 2005. p.411459.

COSCIONE, A.R.; ANDRADE, J.C. \& RAIJ, B.van. Revisiting titration procedures for the determination of exchangeable acidity and exchangeable aluminum in soils. Comm. Soil Sci. Plant Anal., 29:1973-1982, 1998.

EBELING, A.G.; ANJOS, L.H.C.; PEREZ, D.V.; PEREIRA, M.G. \& VALLADARES, G.S. Relação entre acidez e outros atributos químicos em solos com teores elevados de matéria orgânica. Bragantia, 67:261-266, 2008.

EMPRESA BRASILEIRA DE PESQUISA AGROPECUÁRIA EMBRAPA. Centro Nacional de Pesquisa de Solos. Manual de métodos de análises de solo. 2.ed. Rio de Janeiro, 1997. 212p.

EMPRESA BRASILEIRA DE PESQUISA AGROPECUÁRIA . EMBRAPA. Centro Nacional de Pesquisa de Solos. Sistema brasileiro de classificação de solos. 2.ed. Rio de Janeiro, 2006. 306p.

HARGROVE, W.L. \& THOMAS, G.W. Titration properties of Al-organic matter. Soil Sci., 134:216-225, 1982.

MCLEAN, E.O. Chemistry of soil aluminum. Comm. Soil Sci. Plant Anal., 7:619-636, 1976.

MENZIES, N.W. Toxic elements in acid soils: Chemistry and measurement. In: RENGEL, Z. Handbook of soil acidity. New York, Marcel Dekker, 2003. p.267-296.

NISSINEN, A.; ILVESNIEMI, H. \& TANSKANEN, N. Equilibria of weak acids and organic $\mathrm{Al}$ complexes explain activity of $\mathrm{H}^{+}$and $\mathrm{Al}^{3+}$ in a salt extract of exchangeable cations. Eur. J. Soil Sci., 50:675-686, 1999.

PEREIRA, M.G.; ANJOS, L.H.C. \& VALLADARES, G.S. Organossolos: Ocorrência, gênese, classificação, alterações pelo uso agrícola e manejo. In: VIDALTORRADO, P.; ALLEONI, L.R.F.; COOPER, M.; SILVA, A.P. \& CARDOSO, E.J., eds. Tópicos em ciência do solo. Viçosa, MG, Sociedade Brasileira de Ciência do Solo, 2005. v.4. p.233-276.

RAIJ, B.van; CANTARELLA, H.; QUAGGIO, J.A.; PROCHNOW, L.I.; VITTI, G.C. \& PEREIRA, H.G. Soil testing and plant analysis in Brazil. Comm. Soil Sci. Plant Anal., 25:739-751, 1994

ROSS, D.S.; MATSCHONAT, G. \& SKYLLBERG, U. Cation exchange in forest soils: The need for a new perspective. Eur. J. Soil Sci., 59:1141-1159, 2008.

SCHINITZER, M. \& SKINNER, S.I.M. Organo-metallic interactions in soils: 2 . Reactions between different forms of iron and aluminum and the organic matter of a Podzol Bh horizon. Soil Sci., 96:181-186, 1963.

SHUMAN, L.M. Comparison of exchangeable Al, extractable $\mathrm{Al}$, and $\mathrm{Al}$ in soil fraction. Can. J. Soil Sci., 70:263-275, 1990. 
SIMONSSON, M. Interactions of aluminum and fulvic acid in moderately acid solutions: Stoichiometry of the $\mathrm{H}^{+} / \mathrm{Al}^{3+}$ exchange. Eur. J. Soil Sci., 51:655-666, 2000.

SOIL SURVEY STAFF. Soil taxonomy: A basic system of soil classification of making and interpreting soil surveys. 2.ed. Washington, USDA-Natural Resources Conservation Service, 1999. 869p. (USDA. Agriculture Handbook, 436)

SOON, Y.K. The fractionation of extractable aluminum in acid soils: A review and a proposed procedure. Comm. Soil Sci. Plant Anal., 24:1683-1708, 1993.
SPARKS, D.L. Environmental soil chemistry. 2.ed. San Diego, Elsevier, 2003. p.267-283.

SPOSITO, G. The chemistry of soils. New York, Oxford University Press, 1989. p.209-225.

VEITH, J.A. Basicity of exchangeable aluminum, formation of gibbsite, and composition of the exchange acidity in the presence of exchangers. Soil Sci. Soc. Am. J., 41:865870, 1977.

YUAN, T.L. Determination of exchangeable hydrogen in soils by a titration method. Soil Sci., 88:164-167, 1959. 